\title{
THE LAW POLITICS IN THE REFORMULATION OF INTERFAITH MARRIAGE IN INDONESIA
}

\author{
Teti Hadiati ${ }^{1} \&$ Makrum $^{2}$ \\ Institut Agama Islam Negeri Pekalongan \\ Jl. Kusuma Bangsa Kota Pekalongan Jawa Tengah \\ Email: ${ }^{1}$ teti.hadiati@iainpekalongan.ac.id; ${ }^{2}$ makrum@iainpekalongan.ac.id
}

\begin{abstract}
The problems examined in this study is whether interfaith marriages are in accordance with the philosophical values of Indonesian marriage law, and why is the validity of interfaith marriages still being disputed in Indonesian marriage law. Related to the principle of continuing legal conditions and public order, the implementation of registration marriage by registration is a form of acceptance of interfaith marriages and the community has accepted the phenomenon of interfaith marriages as a natural reality and is considered to be true. This research is a normative legal research and quantitative sociological legal research. The study methodology is analyzed based on the principle of public order, law smuggling, and continuation of the legal situation or rights that have been obtained. From this research, it was concluded that interfaith marriages were considered incompatible with the philosophical values of Indonesian Marriage law which were based on religious law, and could injure the long struggle history of Indonesian marriage law legislation with the principle of public order. Therefore, the registrations carried out by the civil registry office are not authoritative, but are merely administrative in nature.
\end{abstract}

Keywords: Political Law, Marriage, Difference in Religion

\begin{abstract}
Abstrak: Permasalahan yang dikaji dalam penelitian ini adalah apakah pernikahan beda agama sesuai dengan nilai-nilai filosofis hukum perkawinan Indonesia, dan mengapa validitas perkawinan beda agama masih diperdebatkan dalam hukum perkawinan Indonesia. Terkait dengan prinsip berlanjutnya kondisi hukum dan ketertiban umum, pelaksanaan pendaftaran perkawinan dengan registrasi adalah bentuk penerimaan perkawinan beda agama, dan masyarakat telah menerima fenomena perkawinan beda agama sebagai kenyataan alamiah dan dianggap benar. Penelitian ini adalah penelitian hukum normatif dan penelitian hukum sosiologis kuantitatif. Metodologi penelitian dianalisis berdasarkan prinsip ketertiban umum, penyelundupan hukum, dan kelanjutan dari situasi hukum atau hak-hak yang telah diperoleh. Dari penelitian ini, disimpulkan bahwa pernikahan beda agama dianggap tidak sesuai dengan nilai-nilai filosofis hukum perkawinan Indonesia yang didasarkan pada hukum agama, dan dapat melukai sejarah perjuangan panjang undangundang perkawinan Indonesia dengan prinsip ketertiban umum. Oleh sebab itu, pendaftaran yang dilakukan oleh kantor catatan sipil tidak sah, tetapi hanya bersifat administratif.
\end{abstract}

Kata kunci: Politik Hukum, Perkawinan, Perbedaan Agama

\section{Introduction}

The pattern of relations between religion and state is very dynamic in Indonesia. In this case religious groups are represented by Islamic groups because the majority of Indonesian people are Muslims. Especially here are ideological and political Islam groups. While the state is represented by the government which generally tends to be from secular nationalist groups. Since pre-independence until the new order there were often tensions in relations between Islam and this country. This tension is mainly related to Indonesian political and party politics.

During this time in Indonesia, there is a known political flow referred to in the political grouping of the 1950s. The pattern of political grouping occurs due to the similarity of cultural orientation, namely the bonding of a group of people to the dominant culture within the group and grouped into santri, priyayi and abangan 
groups. In the party, each sect is represented by the NU and Masyumi parties as the Santri party, PNI is the priyayi party and the PKI is the abangan party.

During the Dutch East Indies, attempts to carry out unification in the field of civil law failed, then what happened was the existence of a plurality of laws in the field of civil law. While the exclusion jurisdiction is returned to customary law, besides customary law in Indonesia there are also religious laws, especially Islamic law in some areas and modified with customary law.

\section{Methode Result}

This article is to determine the method of normative and empirical legal research with the typical characteristics of the methods of researching Law. The approach used qualitative methods through the study of literature. Based on the research findings and discussion, it can be concluded, first, science law (jurisprudence) and all sub-study with him in a large family study of the law, no matter how controversial as as a discipline independent and peculiar (sui generis), part from the humanities and social sciences, as well as natural science (exact) and social sciences which has had an undeniable place in the branches of science. Science of law must be recognized as having the research methods typical and unique, in terms of interest / usefulness to do a research in the field of law, both theoretical and practical, or of how to look at the science of law as a discipline prescriptive and applied, as well as from the point of view of human behavior relating to the existence of the law.

\section{Discussion}

\section{Dutch East Indies Period}

Prohibition of Inter-moslem Marriage with non-muslims in Nusantara (Indonesia) has been found in the earliestfiqh books. Abdurrauf syiah kuala has mentioned widely in his book "mir'atutthullab", a fiqh book which was writtenas the request of the queen of Aceh Darussalam (shafiatus syah) in the $17^{\text {th }}$ century AD. After this the interfaith marriage ban was given by Jalalludin at turasani in his book entitled "safinat al-hukm fi takhlis al-kassham" this book was written on the request of the Sultan 'Alaudin Syah as the handle of the royal judge Aceh Darussalam in order to complete the book "Mir'atutthullab" which was already there after this Sheh Arsyad al Banjari in the minutes the small one entitled "Risalah Nikah/ marriage treatise" and almost all books of marriage mention the prohibition of marriage due to religious differences. ${ }^{1}$

Christianity came more recently from Islam to the Nusantara's archipelago, first brought by the Portuguese as the first western nation to the archipelago to trade and explore in the late $15^{\text {th }}$ century AD. They searched for their own way to get to the archipelago with a very high enthusiasm. Because it was motivated by two things: 1 . they only succeeded in driving Islam out of the Iberian peninsula in 1492, 2. They were very impressed by Columbus's journey to India but to find America.

Moreover, the spice trade that used land routes from China to Europe was disrupted because the East Lenk's invasion of the Middle East and later the emergence of a small diocesan Usmaniah Sultanate in the $15^{\text {th }}$ century could also take Constantinople from the hands of the East and make it the Ottoman Islamic capital. In order to find a source of spices in order to get huge profits, the Portuguese wanted to monopolize from the source in Maluku to Europe, so they tried to control the area that was the source of the trade, such as Kalikut and Goa in India and Malacca and Timor in the archipelago. and several countries in Africa.

In addition to securing its trade routes, the control of the area was also used to spread Christianity. Their spirits was increasingly high

${ }^{1}$ Alyasa Abubakar, The Marriage between Muslim and Non Muslim, (Aceh: Dinas Syari'at Islam Provinsi Nanggroe Aceh Darussalam, 2008), p. 17. 
because of the territory they had just visited and had to deal with Muslims. The people they have to deal with poorly on the Iberian peninsula. His religion is spread in Maluku and East Timor. In this religion, the interfaith marriages are considered illegal and tend to be strictly prohibited. $^{2}$

The Dutch who arrived at the end of the $16^{\text {th }}$ century succeeded in succumbing to the Portuguese, also spreading Protestantism. At the beginning of his arrival, the Dutch did not carry the name of the country. They formed a VOC company in 1602. The VOC was not only given permission to monopolize, it was also given permission to make agreements with the kingdom and to control and seize the areas it deemed necessary so that the VOC had two characteristics: 1 . Board for partners to trade 2 . board to govern.

Although the VOC has the character to govern, it emphasizes its trade mission rather than the mission to control the territory and the spread of religion even though it cannot be clearly separated from the beginning, but they also prohibit the interfaith marriages, especially for religious Europeans and religious natives, non-Christian

Because of bearing the loss, this trading company was dissolved in 1800 and the Dutch government took over all of the VOC's responsibilities and debts. Since then the Dutch have gripped the nails of their occupation more directly and tried to establish their power in such a way and for that they put their attention to religion and the rules of law that prevail among the indigenous people. They interfered in even changing the various laws that were in the midst of society with Dutch law or other laws that favored their occupation.

In this Dutch Colonial period, the separation of population based on religion tended to be relaxed, but new dividers were based on origin,

\footnotetext{
${ }^{2}$ Alyasa Abubakar, The Marriage between Muslim and Non Muslim, p. 18-19.
}

and customary law. ${ }^{3}$ The Dutch has observed the Indies community find that Islam has developed well, especially in marital matters because in Islam,the Islamic marriage is a very important thing that is a sign of the perfection of one's Islam. Therefore, if North Sumatra intends to interfere with customary law, it is often confronted with Islamic law which has been properly observed by the community. Then the Dutch conducted research on the law in force in the community, and found that the applicable law was Islamic law. The codification they have made from the results of this research include MUGHARRER (compendium der voornaamste javaansche wettennawwkeuringgetrokkenuit het muhammedanse wetboek moegharrer) in 1747 . It was made as a court handle in Semarang and in Pepakem of Cirebon (Cirebonscherechtsboek) in 1765. ${ }^{4}$ It was also happened in South Sulawesi. There is an Indiansche compendium wettenbij de hoven van bone en Goa. ${ }^{5}$ Furthermore, Dutch legal politics seeks to separate the law of Islam from society, which is famous for Receptie's theory, namely the new Islamic law will apply if it has been accepted as customary law by the community concerned. If a Muslim community is effective in carrying out Islamic law in the midst of society, then the law cannot run. ${ }^{6}$

Result that interfaith marriages performed abroad can be considered incompatible with the values of the philosophy of the Indonesian marriage law which is based on religious law. However, roceduraly the records obtained interfaith marriages, the office of Civil Registry officials only register the marriage. This registrasion doesn't relate to the validity but administrative in nature only. The politics of the Dutch law at that time was mainly related

\footnotetext{
${ }^{3}$ Alyasa Abubakar, The Marriage between Muslim and Non Muslim. p. 25.

${ }^{4}$ John Ball, Indonesian Legal History 1602-1848, (Australia: Chatswood NSW, 1982), p. 57 and 60. Also recited by Alyasa Abubakar, The Marriage between Muslim and Non Muslim, p. 21-22.

5 Ratno Lukito, Islamic Law and adat Encounter: The Experience of Indonesia, (Jakarta: Logos, 2001), p. 37.

${ }^{6}$ Alyasa Abubakar, The Marriage between Muslim and Non Muslim, p. 23.
} 
to civil law ${ }^{7}$, which was the resettlement of the population and the application of the law which was different for each group, and on the other hand by reducing the enforcement of Islamic law in the community. In addition, in the early days, the Dutch also tried to separate the Indian Hindus based on their religion. It appears that people who are Christians are equated with European, indigenous, Chinese or Arabic groups, but in the end the separation of population based on religion is relaxed. The circumstances of diverse populations tend to be given the freedom to implement their own customary law. so also made the rules of liaison between citizens of various groups of population, especially in the period of marriage, namely the regulation of the mixture or regulation of de gemendehuwelijken (ghr) this regulation is strong not in the royal kingdom of 29 December 1896 in this regulation mentioned: "difference of origin legal proposals or positions should not be a barrier to marriage.In 1901, a rule was added thatreligious differences cannot be used as a barrier to carrying out mixed marriages (article 7 point 2). With these regulations, interfaith marriages are granted and regulated legally. ${ }^{8}$

\section{After Indonesia's Independence Period}

After independence, Indonesia tried to form its own law which was independent of colonial Dutch law. related to the renewal of marital law dated November 21, 1946, the law concerning marriage, divorce and referral was issued. namely Law No. 22 of 1946. At that time the Indonesian people were facing the Dutch who were about to re-colonize, so that the enactment of the Law for the Republic of Indonesia could not yet be done. The law only applies in Java and Madura. Only on 1954 with Law number 32 of

\footnotetext{
${ }^{7}$ The earliest citizen law was mixed is pidana law. Their reason is humanity reason, its because their law only know penalties with imprisonment and fines, are considered more humane than traditional criminal penalties in force in the community such as eviction, caning, and the death penalty, Alyasa Abubakar, The Marriage between Muslim and Non Muslim, p. 23.

${ }^{8}$ Alyasa Abubakar, The Marriage between Muslim and Non Muslim, p. 26-27.
}

1954 that the Act was enacted for all Indonesian regions. ${ }^{9}$

The law is not only regulated by recording but explicitly emphasizes that PPN assignment (Marriage Record Officer) is: 1 oversees marriage conducted according to Islam. 2 records the marriage and accepts the informant then records all the divorce and reconciliation given to him. Those intended to oversee the explanation of this law are: a). The PNP must be present at the time of the marriage contract and then record it b) check when the parties declare their intention to marry, is there a good obstruction according to Islamic law or according to the law. if there is an obstacle, the PPN refuses to carry out the marriage. ${ }^{10}$

Furthermore, The efforts to reform marital law again for this effort came from nationalists who sought the unification of Indonesian marital law that was different from Dutch law, especially in terms of marriage and divorce. this marriage law will later become Indonesia's national marriage law that accommodates national aspirations set for all Indonesian people regardless of ethnicity or religion.

The attempt to form a unified national marriage law began in 1950, regardless of the new religious law in 1952 religious materials formed the committee drafting the draft marriage law from religious groups. This group overrides its original purpose and replaces it with draft formulation based on different religious laws. In 1954, this committee completed its task. They have drafted the marriage. The Islamic draft was not yet discussed in the DPR until 1958 because there was a counter from a religiously neutral nationalist group. then the deatlock discussion, a new effort was made by the government by submitting two draft marriage bills to the DPR. In 1967, the Muslim Marriage Act and the 1968 Marriage Law based on the principle of

\footnotetext{
${ }^{9}$ A. Wasit Aulawi, "Sejarah Perkembangan Hukum Islam" dalam Pengurus Pusat Ikatan Hakim Peradilan Agama, Prospek Hukum Islam, p. 83.

${ }^{10}$ A. Wasit Aulawi, “Sejarah Perkembangan...”, p. 84.
} 
religious law were applied to all religious groups. Legislative debates about the RUU did not produce results.

The failure of the discussion of the unique marriage bill was due to a conflict of interest between various groups. Islamic groups want to implement Islamic marriage law, while the Christian group Tidik wants the influence of Islamic law. they want a marriage law that can accommodate the interests of minorities in accordance with their social, political and economic life. Chinese groups also tend to reject the attempt at unification. Because the unification will put them on par with other Indonesian people if the principle of Islamic law will also be applied to them.

With the failure to discuss the unique marriage draft bill, due to a conflict between the various groups, the government submitted a new marriage bill draft to the House of Representatives on July 31, 1973. This new draft submission also caused controversy again, especially among Muslims from the ministry neither religion nor Muslim leaders are invited to discuss it beforehand. more than that, they felt that the article in the new draft bill was contrary to Islamic law, and was considered to have eliminated the influence of Islam in this country and it was not surprising when rumors emerged about Christianization. ${ }^{11}$

\section{Controversy in Article-Section}

The articles which are considered controversy in the marriage bill include: first, article 2 paragraph 1 which emphasizes the registration of civilians is important the validity of marriage for Muslims. second, articles 3 and 40 emphasize that Muslim divorce must be carried out in a

\footnotetext{
${ }^{11}$ Azyumardi Azra, "The Indonesian Marriage Law of 1974: An Institutionalization of Social Changes, " in Arskal Salim and Azyumardi Azra(Eds.), Sharia an Politics in Modern Indonesia, (Singapore: ISEAS, 2003), p. 82. Katz\&Katz, Indonesian Marriage Law, on page. 660; Antony H Johns, "Indonesia Islam and Cultural Pluralism", dalam John L. Epsosito (ed.)Islam in Asia: Religion, Politics And Society, (NewYork: Oxford University Press, 1987), p. 217-218.
}

state court and polygamy must be with the permission of the state court. Third, article 11 paragraph 2 emphasizes that interfaith marriages are not blocked. Fourth, article 8 letter $\mathrm{c}$ and article 62 which see the status of adopted children as the status of biological children. Fifth, articles 13 and 49, which provide legality for engagement and emphasize that pregnancy during engagement can be recognized if the male will marry the woman, and will give legal status to the child born later. ${ }^{12}$

These articles are considered not in accordance with Islamic law. In Islamic law, the validity of marriage lies only in the fulfillment of the pillars of marriage, such as the presence of two bride and grooms, guardians for prospective brides, two witnesses, dowry or dowry and the jade of the cow. Recording of marriage is not given to the validity of marriage in Islamic law. That is also the case for divorcing and polygamy. for Muslims, going to the state court means making the Islamic Courts under a state court, and that is against God's law

According to them, the Islamic Court is a symbol of the authority and guarantee of being enforced by the Shari'ah Islam. Muslims see these articles eliminate the great power of Islam in Indonesia, and eliminate the large functions in Indanesia. which has been implemented and law number 14 of 1970 concerning the main authority of the judiciary at that time, then in the RUU article there is also no doubt that there are obstacles to interfaith marriages.

This is considered contrary to Islamic law. This interfaith marriage is as rejected by Muslims in its long history since the days of Dutch India. that is, with the existence of a mixed marriage regulation in 1898 this interfaith marriage was rejected by Muslims because it was considered incompatible with Islam. and with this marriage means allowing Muslim women to marry nonMuslim men and allowing efforts to legalize Christianity and finally the children of these mixed marriages to become non-Muslims, the

\footnotetext{
${ }^{12}$ Azyumardi Azra, “The Indonesian Marriage Law...”, p. 83.
} 
Islamic leaders criticize the proposed articles as veiled Christianization. ${ }^{13}$

The other two articles, namely about the status of adopted children as well as biological children, are also considered controversial, this article also prohibits adopted children from marrying their adoptive parents. Because of that the article of the Muslims is also the articles about the status of engagement and children born in engagement. Muslims refuse to give the legal status of engagement and children born due to their engagement consider the child an extramarital child. ${ }^{14}$

The debate also took place in the discussion of article 2 paragraph 1 of the marriage law regarding the term trust which is actually a form of compromise as a result of the attraction of political interests when discussing the marriage bill in the DPR. While groups who want to emphasize their desire to make marriages according to the sect of religion as well as religion, as the determining basis for the legitimacy of the marriage that is held by people who adhere to it. the urging of this desire has been rejected by the majority of members of the DPR and the government, because both in the GBHN and the view of the Indonesian nation the belief flow is not religion, but only culture, so that it cannot be used as the legal basis for the implementation of marriage. ${ }^{15}$

In an effort to prevent the deadlock in ratifying the bill, the formulation of the compromise was accepted which in principle did not violate the purpose of the law, namely that religion alone was the legal requirement for marriage. but psychologically does not harm the group that carries these aspirations. the word trust is also found in article 29 paragraph 2 of the 1945

\footnotetext{
${ }^{13}$ Azyumardi Azra, "The Indonesian Marriage Law...”, p. 83.

${ }^{14}$ Daniel S Lev, Peradilan Agama Islam di Indonesia: Suatu Studi Tentang Landasan Politik Lembaga-Lembaga Hukum, Alih Bahasa Zaini Ahmad Noeh, (Jakarta: Intermasa, 1986), p. 340.

${ }^{15}$ H.M. Thahir Azhary, Menegakkan Syariat Islam dalam Konteks Keindonesiaan: Proses Penerapan Nilai-Nilai Islam dalam Aspek Hukum, Politik dan Lembaga Negara, (Bandung: Mizan, 1997), p. 93.
}

Constitution. in its entirety its meaning is then taken and seen behind the word "religion", so that in each word 'religion' is followed by the word "belief" behind the word "religion" the law does not give any meaning so it can be put aside. ${ }^{16}$

\section{The Legislation Process}

While in the DPR session there was a debate, outside the DPR building there were also demonstrations carried out by Muslim activists. the parliament building was occupied by Muslim demonstrators, so the government agreed to accept fundamental changes in the bill. President Soeharto finally agreed with the Union of Development Faction (FPP) in the DPR to change the articles that were contrary to Islam, finally the revision of the Bill could be carried out by the DPR until December 22, 1973. The bill was signed by the president on January 2, 1974, as Law number 1 of 1974 concerning marriage. As implementing regulations. Establishment of government regulation number 9 of 1975 governing marriage and divorce. ${ }^{17}$

It did not occur to the government to implement the draft law on marriage without the opportunity for improvement and improvement by the DPR. because in the Republic of Indonesia's system of administration, the DPR is a partner of the government in the process of legislating the desire to perfect the RUU reflecting beautiful colors and benefiting the democratic life of parliamentary.

Regarding the issue of article 2 of the Bill which FPP deems to be imperfect because it does not emphasize the legality requirements according to religion or the FPP is expressed as if the recording aspect is the superiority of the continuity of marriage according to religion. actually this is not what was intended by the government because it was very clearly determined that the marriage was carried out according to the legal provisions of marriage of

\footnotetext{
${ }^{16}$ H.M. Thahir Azhary, Menegakkan Syariat..., p. 94.

${ }^{17}$ AzyumardiAzra, "The Indonesian Marriage Law...", p. 84.
} 
the parties to the marriage which meant that for Indonesian Muslims with Islamic law that had been accepted by adat as necessary for the presence of a guardian, a number of witnesses, a statement on the consent of the cowboy, the presence of dowry (dowry) and so on. ${ }^{18}$

\section{Pro-Contra to Legislasi}

The bill reaps various community responses, both pro and con. tempo magazine reports that history in India has never had a bill legislation that has been released from public attention, various Islamic organizations including the Aceh ulama council. Youth Generation IslamIndonesia (GMII), Indonesian Islamic Students (PII), Nahdatul Ulama Student Association (IPNU), ties to Muslim scholars IPPNU), the Muhammadiyah Student Association (IPM), also some individual Muslim leaders rejected the marriage bill based on their belief that interfaith marriages contradict Islamic teachings, for example Anwar Harjono cited the MUI fatwa that interfaith marriages are unlawful, because the mafsadah is more than the benefits. ${ }^{19}$

According to him, Muslims reject different religious marriages in the marriage bill purely based on religious beliefs not political even though in the GBHN it is stated that it is important to have nationally uniform laws that govern all citizens. All aspects of life he also stressed that in family law matters, unique national laws can only regulate aspects of non-religious and non-cultural life, such as assets and contracts not problems related to religious aspects such as marriage, divorce, and inheritance. $^{20}$

Rasjidi was also the strongest figure in opposing the marriage bill, in his book the case

\footnotetext{
${ }^{18}$ Daniel S Lev, Peradilan Agama..., p. 330-340.

19 Anwar Harjono, "Renungan Menjelang Ramadhan, "Media Dakwah, March 1992, p. 6-7 dikutip dalam Fatimah Husein, Muslim Christian Relations in the New Order Indonesia: The Exclusivist and Inclusivist Muslims' Perpective, (Bandung: Mizan, 2005), p. 198-199.

${ }^{20}$ Tempo, "RUU Perkawinan: Mencabut dan Merubah", 22 September 1973, p. 8-9.
}

of marriage in Islamic and Christian relations he argued that interfaith marriage was not permissible in Islam, he referred to the marriage case in the Solo palace in July 1973 a few months before the marriage bill was debated. the marriage event of Supiah Putu Susuhunan Sultan Prabu Pakubuwono XII who married a Christian named Sylvanus from Kalimantan.

According to Rasjidi, the fact that Supiah was not permitted to marry Abdullah Suwarna, who is of various Islamic backgrounds, instead married a Christian, this proves that the effort to legalize interfaith marriage. Rasjidi argues that there is a movement to make interfaith marriages a normal and normal practice, as stated in the marriage bill.

Rasjidi stated that the bill was only an attempt to Christianize $90 \%$ of Indonesia's diverse population of Muslims and that it was an effort to critique even though he also stated that not all Catholics and Christians want to attract Muslims into their religion. Rasjidi also believed that there were Christian missionaries who supported the marriage bill as well as their efforts in the context of Christianization of Indonesian Muslims. ${ }^{21}$

The debate in the DPR about the marriage bill also continued in the newspapers, each from Islam and Christianity defending each other's arguments, Rasjidi's view that the Christianization effort was published in several newspapers such as US. Nusantara and perpetual on August 19, 1973. On December 12, 1973, a Protestant union newspaper, a ray of hope exposes a memorandum issued by the Indonesian youth generation unitary committee stating that the state cannot and must not implement religious teachings to its followers including marriage problems. in other words, the state must guarantee the freedom of all citizens to carry out interfaith marriages.

In the edition of the compass (Catholic newspaper) and the light of hope responds to the

\footnotetext{
${ }^{21}$ HM. Rasjidi, Kasus-kasus RUU Perkawinan dalam Hubungan Islam dan Kristen, (Jakarta: Bulan Bintang, 1974), p. 9-12.
} 
issue and states that laws based on religion about marriage will pave the way for the application of laws based on other religions on other aspects of life. a more serious response came from a letter signed by SAE Nabban from DGI and Mawi secretary Leo Sukoto SJ on 12 December 1973 which contained:

1) Based on article 29 of the 1945 Constitution that the state guarantees its citizens to embrace their religion and to worship according to their religion and that belief means that freedom to choose is important in religion.

2) During the debate about the marriage bill in the DPR, WE have seen that the state will not only guarantee religious freedom but also stipulate the implementation of religious law, especially regarding marriage.

3) We expect every citizen to carry out marriage based on their respective religious laws. however, if we consider that only the marriage law is one of the true religions, many problems arise related to religious freedom.

Large demonstrations against the marriage bill made the New Order government worried, so the government made fundamental changes to the Bill which later became Law number 1 of 1974 concerning marriage. Article 2 of the Marriage Law states that marriage is valid if carried out according to each religious and belief law. however, there are still many criticisms of this new formula. The Indonesian republican Catholic student association stated that the revision of the bill deviated from the spirit of the Pancasila and the 1945 Constitution concerning guarantees of religious freedom. that this new formula has forced citizens to carry out religious obligations as well as marriage law.

Rasjidi also considers that the strong resistance made by Christians towards the revision of the marriage bill is in opposition to Islamic law support for Christianization. He believes that the core of the refusal of Catholics and Christians to the marriage bill is their perception that religion should not play a role in determining the sociopolitical life of the Indonesian people.

\section{Religious Law in Indonesian Marriage Law}

The marriage law contained in the marriage law is often regarded as a product of religious law, especially among Muslims regarded as a product of Islamic law in Indonesia, when compared to the jurisprudence of the marriage law there are three forms of views namely: first the marriage law fully absorbs and taking fiqh book material, for example about marital barriers both obstacles because of nasab, musaharah or brother of the compilation. secondly, the material of the marriage law does not exist or is regulated in the book of jurisprudence but does not conflict with the book of fiqh for example having to register marriage officially. third, the material of the marriage law is different and contrary to the material of the book, for example the provisions regarding the age limit of marriage in UUP are required by men at least 19 years old and 16 years of women while in the book of fiqh it is not required to age even married Aisha aged 7 years. $^{22}$

If observed more closely in the articles of marriage law, the existence of Islamic law in it in several forms can be seen. First, in its full form as contained in the book of fiqh that is commonly applicable in Indonesia, even syfi'i jurisprudence in whole according to zahir al qur ' for example in the prohibition of marriage. Second, Islamic law enters into a form that has been adapted to the demands of progress, although it is somewhat different from the jurisprudence prevailing in Indonesia, such as divorce through the court. Third, the material is indeed never discussed in fiqh but can be accepted as fiqh because there is a value of benefit and does not conflict with the existing arguments, for example about the recording of marriage. ${ }^{23}$

Meanwhile, the attitude of Muslims towards the marriage law is divided into three groups. first, it does not recognize the marriage law as a

${ }^{22}$ Amir Syarifuddin, Meretas Kebekuan Ijtihad: Isu-isu Penting Hukum Islam Kontemporer di Indonesia, (Jakarta: Ciputat Press, 2002), p. 48.

${ }^{23}$ Amir Syarifuddin, Meretas Kebekuan..., p. 33-34. 
rule that replaces fiqh. Second, recognizing the marriage law as a law that must be obeyed in its position as a citizen, but as Muslims it also recognizes and carries out the rules of fiqh. third, those who act to consider the marriage law as a state law that legitimately regulates the marriage affairs of Muslims, for this group insofar as it is regulated by the marriage law, fiqh is in a new form that applies in Indonesia. ${ }^{24}$

The view that marriage law is this religious law is not wrong. National law must indeed be inspired and based on the Pancasila (in this case the first principle, the supreme divinity) and the 1945 Constitution, because the Pancasila is determined as the source of all legal sources and is the basis of all legal products in Indonesia. first of all, the supreme divinity both of these require that Indonesian national law be based on the Almighty Godhead for the Indonesian nation this understanding based on the Almighty Godhead is based on religion because the majority of Indonesian people are religious and only a small percentage believe in God Yang The One who is not religious. ${ }^{25}$

According to Thahir Azhari, in the provisions of article 29 paragraph 1 which states that "the state is based on the supreme godliness" basically contains three meaningful contents, namely: ${ }^{26}$

a) The state may not make rules or invitations or carry out policies that are contrary to the basis of faith in the Almighty God.

b) The state is obliged to make laws and regulations or carry out policies for the implementation of a form of a sense of faith in the Almighty God from a group of followers who need it.

c) The state is obliged to make legislation that prohibits anyone from harassing religious teachings.

d) Result that interfaith marriages performed abroad can be considered incompatible with

\footnotetext{
${ }^{24}$ Amir Syarifuddin, Meretas Kebekuan..., p. 49-50.

${ }^{25}$ Amir Syarifuddin, Meretas Kebekuan..., p. 30.

${ }^{26}$ H. M. Tahir Azhary, Menegakkan Syariat..., p. 28.
}

the values of the philosophy of the Indonesian marriage law which is based on religious law. However, roceduraly the records obtained interfaith marriages, the office of Civil Registry officials only register the marriage. This registrasion doesn't relate to the validity but administrative in nature only.

\section{Conclussion}

Based on the explanation, the law of Indonesian marriage is taken from the material of religious law, especially Islamic marriage law and the people's demands when the marriage bill legislation that rejects several articles which are considered contrary to religious law, is not contrary to the 1945 Constitution (especially article 29) as the source of the first higher precepts of law is the Godhead the One as the ground norm or the source of all laws in Indonesia.

Interfaith marriages can be considered incompatible with the philosophical values of Indonesian marriage law that are based on religious law, so that the legality of interfaith marriages in Indonesia is based on religious law in Indonesia and can damage the long struggle for Indonesian Marriage law.Juridically, interfaith marriages in Indonesia are still considered a controversial issue, because there are opinions that say no, and there are those who argue that interfaith marriages are not regulated in Indonesian marriage law, resulting in a legal vacuum, and marriage laws can be re-enacted mix. However, in practice, the recording of interfaith marriages in Indonesia is difficult.

\section{References}

Abubakar, Alyasa. The Marriage between Muslim and Non Muslim, (Aceh: Dinas Syari'at Islam Provinsi Namggroe Aceh Darussalam, 2008.

Aulawi, A. Wasit. "Sejarah Perkembangan hokum Islamdalam Pengurus Pusat Ikatan Hakim Peradilan Agama, Prospek hukum Islam.

Azhary, H.M. Thahir. Menegakkan Syariat Islam dalam Konteks Keindonesiaan: Proses 
PenerapanNilai-Nilai Islam dalam Aspek Hukum, Politik dan Lembaga Negara, Bandung: Mizan, 1997.

Azra, Azyumardi. "The Indonesian Marriage Law of 1974: An Institutionalization of Social Changes", in Arskal Salim and Azyumardi Azra(Eds.), Sharia an Politics in Modern Indonesia, Singapore: ISEAS, 2003.

Ball, John. Indonesian Legal History 1602-1848, Australia: Chatswood NSW, 1982.

Fatimah, Husein. Muslim Christian Relations in the New Order Indonesia: The Exclusivist and Inclusivist Muslims' Perpective, Bandung: Mizan, 2005.

Harjono, Anwar. "Renungan Menjelang Ramadhan, "Media Dakwah, March 1992.

Johns, Antony H. "Indonesia Islam and Cultural Pluralism”, dalam John L. Epsosito (ed.) Islam in Asia: Religion, Politics And Society, NewYork: Oxford University Press, 1987.
Lev, Daniel S. Peradilan Agama Islam di Indonesia: Suatu Studi Tentang Landasan Politik Lembaga-Lembaga Hukum, Alih Bahasa Zaini Ahmad Noeh, Jakarta: Intermasa, 1986

Lukito, Ratno. Islamic Law and adat Encounter: The Experience of Indonesia, Jakarta: Logos, 2001.

Rasjidi, H.M. Kasus-kasus RUU Perkawinan dalam hubungan Islam dan Kristen, Jakarta: Bulan Bintang, 1974.

Syarifuddin, Amir. Meretas Kebekuan Ijtihad: Isu-isu Penting Hukum Islam Kontemporer di Indonesia, Jakarta: Ciputat Press, 2002.

Tempo, "RUU Perkawinan: Mencabut dan Merubah”, 22 September 1973.

Wardaya, Kusuma "Marriage Law in Indonesia and Australia A Comparative Analysis", Jurnal Voice of Constitusion and Human Right, Vol. 2, No. 2, Februari 2009, Lembaga Penelitian Universitas Sebelas Maret Surakarta 